\title{
Role of Macro and Micronutrients in the Growth and Development of Plants
}

\author{
Victoria Joan Johnson and Anis Mirza*
}

Department of Horticulture, SAGR, Lovely Professional University, Phagwara, Punjab, India

*Corresponding author

\section{A B S T R A C T}

\begin{tabular}{|l|} 
Key w or d s \\
Macro and \\
Micronutrients, \\
Growth \\
development, Plants \\
\hline Article Info \\
\hline $\begin{array}{l}\text { Accepted: } \\
\text { 07 October } 2020 \\
\text { Available Online: } \\
\text { 10 November } 2020\end{array}$ \\
\hline
\end{tabular}

Micronutrients and macronutrients are useful elements for plant growth and development. When these are made unavailable to the plant, the soil health gets deteriorated and toxicity levels increase in the soil, as a result the plant withers and dies. Macro and Micronutrients deficiency are verified by various soil and plant analysis. The deficiencies of various micro and macronutrients are increasing due to high crop yields, which cause an increase in the nutrient uptake demand for the fruit crops. These nutrients are used for the enhancement in plant growth and development. When Macronutrients are applied to the soil, it increases the fertility, fixes nitrogen bacteria in the root nodules and enhances the growth of the plant, increase the vegetation and fruit development. When Micronutrients are applied to the foliage of the plant, various essential nutrients are absorbed which increase the mobility of the nutrients in the foliage. These nutrients are essential as they maintain the stability and the production in plants. In this review the classification and types of nutrients, how nutrients are transported, the types of nutrient deficiency symptoms, when there is a deficiency of nutrients, what are the remedies used and the role of micronutrients in fruit crops have been discussed.

\section{Introduction}

The elements of plants for the uptake of nutrients occurs by micro and macronutrients, these are responsible for the growth and the development of plants. Micronutrients are required in small quantities whereas Macronutrients are required in large Disease resistance and the production of crop is maintained by micronutrients (Gupta et al., 2008). Major nutrient uptake and metabolism activities in plant and various process like development of plant cell wall, photosynthesis, respiration activities, formation of chlorophyll, activity of enzymes, synthesis of hormones, fixation of nitrogen and reduction activities etc, Micronutrients increase the quality, yield and post-harvest life of horticulture produce (Raja, 2009). Foliar feeding supplies micronutrients, hormones and spraying of nutrients to plants.

The response of plant is fast and less product is required for each feeding. Foliar fertilizer application helps in the increase of pest and disease resistance, yield, tolerance of drought and increase in quality of crop. Potassium application as foliar spray at cantaloupe fruit 
maturity development increased the ascorbic acid and its sugar content and fruit firmness, beta carotene levels increased on potassium foliar application (Lester et al., 2007). Frumone ${ }^{\circledR}$ a new foliar fertilizer helped in improving fruit set and fruit quality of papaya (Ding et al., 2008). Micronutrients such as Zinc, Fe, Boron, Calcium in various forms and others enhance the growth and development of Papaya. Nutrition of papaya is different from crop to crop as their fruiting habitat and yield is different. Foliar application of nutrients is essential to the plants for their growth, yield and fruiting quality. These micronutrients reach the leaves directly on application at the site of metabolism.

All soils are rich in nutrient, soils become deficient in nutrients due to leaching and various soil depletion factors. A deficient soil is poor in nutrient deficiency and this is corrected by the application of various applications of manure and fertilizers. Micronutrients differ in their mobility in the plants. In mobile element deficiency symptoms can be observed in older leaves as the plants transport nutrient from older leaves to young leaves. In mobile elements, the deficiency occurs in lower (older) leaves as nourishment is given to younger leaves than the older leaves. In immobile elements, the deficiency appears on young leaves as the plants fail to transport nutrients from older to younger leaves after absorption.

Micronutrient toxicity occurs due to excessive application, irrigation water containing salts and high mineral content in soil. When the non-essential elements are applied in high amount such as Cadmium (cd), Lead $(\mathrm{Pb})$, Arsenic (As) high toxicity occurs to the plants and livestock and an imbalance occurs in the absorption of nutrients resulting in toxicity and deficiency.
Macronutrients are the nutrients which are absorbed by the plants in large quantities. These are also called as major nutrients. Carbon, hydrogen and oxygen are known as the structural elements which arise from the air and water. Macronutrients consist of both primary and secondary nutrients which arise from soil, fertilizers and others. Nitrogen, phosphorus and potassium are the primary and important nutrients these are added to the soil at the time of sowing or after and during intercultural operations (Fageria, 2005; 2007; Fageria and Baligar, 2005). Deficiency or excess application can lead to many disorders both to the plant as well as fruit. Calcium, magnesium and sulphur are considered as secondary nutrients which are given in later stages. These are added for enhancing the quality of the crop and fruits. Macronutrients are highly absorbed by the plants, the dosage for application should be correct, failing which toxicity and death of the plant can occur (Suryawanshi, 2020).

\section{Nutrients}

These are essential for plant life. Baron Justus Von Liebig first discovered nutrients in the $19^{\text {th }}$ century. There are 16 elements in total out of which Carbon, Hydrogen and Oxygen are essential elements these are absorbed by Water and Carbon dioxide. The remaining elements are namely micronutrients, primary and secondary nutrients. These are taken up by the soil.

\section{Classification of nutrients}

There are two types of nutrients namely,

Macronutrients.

Micronutrients (Suryawanshi, 2020)

Macronutrients: These are taken up by the plants in larger quantities and they are called as Major Nutrients (Suryawanshi, 2020). 
Structural elements: These are important nutrients which are taken up by the air and water. They are Carbon, Oxygen and Hydrogen. Macronutrients are further divided into:

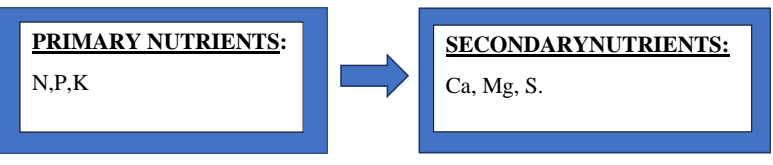

Micronutrients: These are absorbed by the plants in smaller quantities. These are of various types namely:

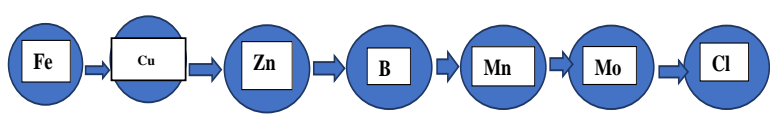

According to Bukovac and Whitter (1957) nutrients are classified as follows:

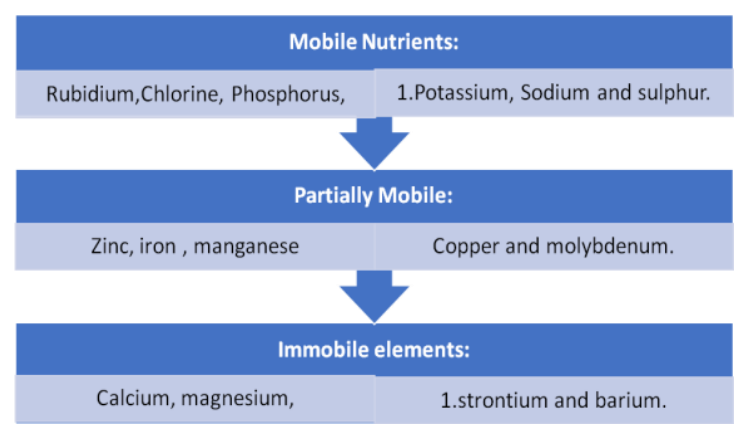

\section{Materials and Methods}

Solid: Urea is applied to the soil in form of granules as it undergoes slight decomposition by the enzyme urease this is secreted by soil micro-organisms. These are absorbed in the soil by irrigation or rainfall (Bryla and Machado, 2011).

Urea can also be mixed along with irrigation water and applied as fertigation to the crop. In crops like blueberry the requirement of nitrogen depends on soil characteristics, fertility status of soil and other factors.
(British Columbia Ministry of Agriculture, 2012; Hanson, 2006; Hart et al., 2006).

Liquid: The micronutrients are generally dissolved in water or diluted prior to use. Foliar spray agent contains an alkali metal silicate as an active ingredient which protects both horticultural and agricultural plants from disease injury by spraying on the leaves of the plants. The treatment of plants with this agent provides an increase in crops yield and Quality. Liquid fertilizers have a disadvantage that they contain large quantities of diluents, especially water. Apart from foliar application, the fertilizers are made into liquid form and are injected in frequent applications through irrigation systems (Vargas et al., 2015).

\section{Transportation and mobility}

There are many ways where the water and the nutrients are transported to the foliage of the plants. It can be through cells or between the roots and the leaves. The mode of transportation is different, but the absorption is the same. Xylem and phloem are two important receptors in the vascular system. The entry of nutrients is seen in the vessels, tracheid present in the xylem and the phloem. Water moves from the soil by the roots and is taken up by the vascular system which is further absorbed by the leaf cells. This process is called as Active transport.

This occurs in the phloem of the leaf. Transportation can be short and long-distance type; the short distance occurs within less time and is seen in cells where the transportation of both organic and inorganic nutrients occurs. Long distance is time taking and the mode of absorption is slow, this happens when the vascular system transports the nutrients to the plants (Riedell et al., 2009). 


\section{Leaching of nutrients from plant foliage}

Nutrient loss occurs by various factors such as rainfall, leaching and others. This happens when there is an impairment of cells which takes place outside the plasma membrane. Guttation occurs in plants which contain salts of organic and inorganic salts in liquid form. Nutrients are leached from the plants due to flooding, rainfall, frequent irrigation, water erosion. (Havlin et al., 2004) nutrients are leached out of the soil and lost due to the flow of water (Jiao et al., 2004). Water use efficiency can reduce the leaching of nutrients (Silva et al., 2009; Migliaccio et al., 2010)

\section{Nutrient deficiency symptoms}

In micronutrients and macronutrients, the deficiency and toxicity range are narrow in nature. In boron the toxicity and sufficiency are different for crops. sufficiency ranges from 10-20ppm and toxicity ranges from 200ppm. Older leaves appear scorched and spread near the midrib. Leaves fall prematurely. Stunted growth and chlorosis occur due to micronutrients such as $\mathrm{Mn}, \mathrm{Mo}$, $\mathrm{Cu}, \mathrm{Ni}$ and $\mathrm{Zn}$. McCauley et al., (2009).

Stunted growth: This is a common symptom which is observed in plants. This occurs when the nutrients involved in plant functions are slow and small in nature. plant functions are the stem elongation, protein production and photosynthesis activity.

Chlorosis: Photosynthesis and the production of chlorophyll are important of the plants when nutrients are deficient in nature chlorosis occurs. This symptom can be seen in the entire plant or leaf. In the leaf colour change is seen from light green to yellow, or localized yellow or white spots.

Interveinal chlorosis: It is described as the yellowing of leaf between the veins. The leaf remains yellow and the veins are green. This occurs when the nutrients deficiency occurs. Nutrients such as Boron, Zinc, Nickel and Manganese are subjected to deficiency.

Purple discolouration: In stems and leaves of the plant purplish-red discolouration occur due to levels of anthocyanin (purple colour pigment). This occurs due to cool temperatures, disease, drought, and accumulation of anthocyanin.

Necrosis: plants affected by necrosis turn brown and die. This is observed in the later stages of a deficiency. Death of plant tissue occurs.

Mottling: Spotted, irregular, inconsistent pattern.

These are the various deficiency symptoms which occur in the plants. McCauley et al., (2009).

\section{Types of nutrients and their deficiencies}

\section{Macronutrients}

\section{Primary nutrients}

Nitrogen: Nitrogen is essential for the plant right from sowing to the growth and development of the plant. Increases the vegetation of the crop, size of the leaves increases which enhances the photosynthetic activity of the plant. Increases the fruit growth and production of seeds. Plant metabolism, chlorophyll content, Nucleic acid and proteins, carbohydrates formation and photosynthesis occur by the presence of nitrogen. Excess application of nitrogen increases the vegetative growth which prevents fruit growth due to overcrowding (Suryawanshi, 2020).

Deficiency: Slow growth and stunted nature of the plant is seen as a result the lower leaves are subjected to chlorosis. Foliage of the plant 
turns pale green in colour. The plants which are deficient in nitrogen are subjected to various conditions like decrease in yield and crop quality. Fields deficient in Nitrogen can be patchy or uniform in appearance (Dhok, 2020).

Remedies: Nitrogen is lost due to volatization during hot dry weather and leaching due to runoff. Application of nitrogen-based fertilizer can be done. Denitrification is also seen.

Eg: Ammonium nitrate, potassium nitrate, urea, sodium nitrate, etc. (Suryawanshi, 2020).

Phosphorus (P): This element is essential in young plants for the development of various elements such as sugars, nucleic acids, ATP for energy production. Crop maturation, flowering, fruiting, germination, ripening and enhancing of grain quality is seen with this nutrient. Biochemical reactions including the metabolism of fats, proteins and carbohydrates occur with this nutrient. Phosphorus is a major nutrient which is used in the root development in plants (Dhok, 2020).

Deficiency: leaves and stem turn pale green in colour. Anthocyanin synthesis causes presence of sugars in the leaf as a result the leaves turn purplish in colour. Leaves turn brown and die. The leaf expansion and leaf surface area are inhibited, leaf become small and curling of leaf is seen. Fruits become acidic in nature and have acidic flavour (Suryawanshi, 2020).

Remedies: Application of phosphatic fertilizers is done (Dhok, 2020).

Potassium: This is essential for the photosynthesis, protein formation, sugar transportation, activation of enzymes and co- enzymes. Encourages strong root system, makes the crop resistance to diseases. Lodging of plants is prevented. Tubers are developed, regulation of water is seen, starch formation occurs and carbohydrates are formed (Dhok, 2020).

Deficiency: This deficiency is termed as "HIDDEN HUNGER", as the symptoms are not easily visible. Necrosis and chlorosis cause a reduction in the growth rate of plants. Browning is seen in older leaves. Mottling and leaf burn on the margins occur in the affected leaves. In potassium deficient chlorosis, the midrib is green in colour. Small white spots or yellow spots are present on the leaf margins. Curling of leaf lamina occurs.

\section{Remedies}

Application of potassium fertilizers is done to correct the deficiency symptoms of the crop at early stages. Various potassium fertilizers like Potassium Nitrate $\left(\mathrm{KNO}_{3}\right)$, Muriate of potash (MOP), Sulphate of Potash (SOP) are used at different concentrations based on the crop requirement (Suryawanshi, 2020).

\section{Secondary nutrients}

Calcium (Ca): This is essential for the cell wall formation and it is a component of plant cell walls. Maintains the permeability of cell wall. Essential for cell elongation and cell division. Accumulation of calcium is seen by mitochondria during respiration. Protein content increases on the use of calcium. Translocation of carbohydrates, seed production, root development, chromosome stability, increases nitrogen uptake and helps in nitrogen metabolism (Suryawanshi, 2020). It is important for plant growth and its development (Barker and Pilbeam, 2007). When applied exogenously it increases storage life and firmness of fruit and storage. (Eryani- Raqeeb et al., 2009). Soil application 
is done or foliar spray is done directly on the fruit and leaves to increase the fruit quality (White and Broadley, 2003). Occurs from the root tips, by the cuticle, stomata or the cracks on fruit surface (Saure, 2005).

Deficiency: This is seen in leaves, roots, buds and stems of the plant. Seed germination is poor, dryness and brittle appearance of the leaf tips. Younger leaves are affected and deformation occurs. Development of organs with low transmission rates (White, 2001).

Remedies: Calcium is an essential nutrient in the soil, the deficiency of calcium can be rectified by application of fertilizers like Calcium Sulphate, Calcium nitrate, Super Phosphate and others can be used. If there is lack of calcium in the soil, the fruit characteristics are affected, in peanuts low calcium causes Pops this prevents the development of nuts. Blossom end rot is seen in tomato due to calcium deficiency. Hence it is important to use calcium-based fertilizers for preventing the deficiency symptoms (Suryawanshi, 2020).

Magnesium: This is essential for the production of ATP which is essential for production of energy. It is the central molecule in chlorophyll as the plant constitutes around 15-20\% of total magnesium. Enzyme activity is seen in the cell, formation of peptide chains is seen. Dark green colour is present in the leaf due to magnesium. Uptake of phosphorus occurs, formation of carbohydrates, fats and proteins. Magnesium acts as a mobile element. translocation always occurs from older leaves to younger leaves (Dhok, 2020).

Deficiency: Yellowing of margins, leaf turns reddish - purple while the midrib is still green in colour. Interveinal chlorosis occurs in the leaf. This occurs first in older leaves followed by younger leaves (Suryawanshi, 2020).
Remedies: Gypsum salt and Dolomite is added (Dhok, 2020).

Sulphur (S): this is essential in chlorophyll synthesis and protein symptoms. It is important for protein and amino acid activity. Nodule and seed formation, improves the quality of crops. Coenzyme A and Vitamin B are formed using Sulphur (Suryawanshi 2020).

Deficiency: In young leaves the leaves turn from green to yellow due to chlorosis. The entire plant may turn pale green. Plant deficient in sulphur have small stems and spindly in nature. Maturity is delayed. Younger leaves are affected first. (Dhok, 2020).

Remedies: Gypsum, $\mathrm{K}_{2} \mathrm{SO}_{4}, \mathrm{~K}_{2} \mathrm{Mg}\left(\mathrm{SO}_{4}\right)_{2}$ and others are used (Suryawanshi, 2020).

\section{Micronutrients}

Chlorine: This is essential for the photosynthesis and leaf turgor in plants.

Deficiency: Deficiency of chloride causes physiological leaf spot (Engel et al., 2001).

Remedies: Rain water and irrigation are a source of chlorine, the compounds in chlorine are highly soluble in the soil. Suryawanshi, M. D. (2020).

Molybdenum: Essential for leguminous plants as they fix nitrogen and the enzymatic activity in plants. Nitrogen transformation occurs, nitrogen is fixed when molybdenum acts as a catalyst (Dhok, 2020).

Deficiency: Scorching of leaves, rolling of leaves occurs, leaves becomes thick or brittle, they wither as a result only midrib is present., chlorosis, Whiptail, poor root nodules are formed (Suryawanshi, 2020). 
Remedies: Molybdenum trioxide and sodium molybdates are used (Dhok, 2020).

Boron: This is essential for reproductive tissue formation and cell wall formation. Production of starch, sugar transportation, cell development and formation, hormone, fat metabolism, photosynthesis, salt absorption occurs due to boron. Boron acts an enzyme activator (Suryawanshi, 2020).

Deficiency: death of the terminal bud and growing tips. Leaves turn dark brown, irregular lesions are seen and necrosis occurs. At the base of the leaf whitish yellow spots are seen. Boron deficient leaves get twisted and brittle in appearance curling of leaves occurs as the cell growth gets disturbed. Boron affected plants have a shortened internode and stunted growth is seen. Hen and chicken disorder are seen in grapes. In plants having boron deficiency, seed viability and pollination occurs as boron accumulates the reproductive tissues as a result flower buds fail in formation and become misshapen (Dhok, 2020).

Remedies: Borax is commonly used. (Dhok, 2020).

Iron (Fe): This is essential in the photosynthetic reactions and respiratory functions of the plant. Metabolic reactions, synthesis of porphyrin enzymes like catalyse, peroxidase cytochrome oxidase, production of chlorophyll (Dhok, 2020).

Deficiency: Interveinal chlorosis occurs in young leaves. Chlorophyll production is reduced. Plant growth is slow. The entire leaf has a whitish-yellow appearance and later necrotic appearance is seen. Fe deficient plants are irregular in shape having yellow area (Dhok, 2020).

Remedies: $\mathrm{FeSO}_{4}$, Chelates of Iron, FeEDTA and others are used (Dhok, 2020).
Zinc (Zn): This is essential for internode elongation and hormone production in plants. mobility is intermediate and symptoms arises in middle of leaf. Formation of Auxins, Enzymatic activity is seen (Suryawanshi, 2020).

Deficiency: Young leaves are affected. Interveinal chlorosis occurs between the mid rib and the margin of the leaves. Mottling and striping of leaf occurs. Leaves turn gray-white and fall or die in severe zinc deficiency symptoms. Stunting, sees set and flowering is seen in zinc deficient plants. Little leaf occurs (Dhok, 2020).

Remedies: $\mathrm{ZnSO}_{4}$ is used (Dhok, 2020).

Copper $(\mathbf{C u})$ : This is essential for protein synthesis, respiration and chlorophyll production. It is called as plant poison when used in large amounts. Root metabolism, oxidation and reduction occurs. Ammonium nitrogen is utilized by the plants (Dhok, 2020).

Deficiency: young leaves have chlorosis, lodging, melanosis (brown discoloration), stunted growth and delayed maturity is seen. Dieback, white tips, yellow tips occurs in plants (Suryawanshi, 2020).

Remedies: CuSo4 is used. Suryawanshi, M. D. (2020).

Manganese(Mn): Most sensitive cell organelle to magnesium deficiency is the chloroplast (Mengel and Kirkby, 2001). During Nitrogen assimilation enzyme is activated by Manganese, chlorophyll is manufactured, oxidation and reduction is controlled (Suryawanshi, 2020).

Deficiency: Interveinal chlorosis occurs in younger leaves. Blackish brown or red spots are seen on the leaves due to improper supply 
of chlorophyll in the leaves. Hence chlorosis and necrotic lesions are present (Dhok, 2020).

Remedies: $\mathrm{MnSO}_{4}$ is used on large scale (Dhok, 2020).

Nickel(Ni): This is essential for the germination of seeds. It is essential for the conversion of urea to ammonium, as $\mathrm{Ni}$ is metal component in urease (Dhok, 2020).

\section{Some of the elements used in foliar application}

Frumone®: This product is made of water. It has a wide range of nutrients having amino acids, plant hormones and growth promoters and micronutrients (Ding et al., 2008).

Neem Oil: (Azadirachta indica), this is extracted by cold pressing seeds of neem. Soil fertility is improved as it has antimicrobial properties (Gajalakshimi and Abbasi, 2004).

NAA: Napthalene Acetic Acid (NAA): synthetic form of auxins. It is cell elongation, cells division, vascular tissue, differentiation, root initiation, vascular tissue, differentiation, root, initiation, apical dominance, leaf abscission, fruit setting and flowering (Singh et al., 2018).

Gibberellic acid: Stimulation in the plant growth and development. Transitions occurs right from the meristem of the plant to flowering stage and is used to know the sex expression (Gupta and Chakarbarty, 2013).

Copper sulphate: Photosynthesis protein carbohydrate formation in agricultural plants.

Deficiency: Necrotic symptoms are seen over young leaves which results in defoliation of the foliage (Prasad, 2008).

Manganese sulphate: It is important for cell division and cell development. destruction of
Indole-3 acetic acid (IAA) occurs. Activation of decarboxylase, oxidase enzymes which are essential in nitrogen metabolism and nitrogen assimilation.

Deficiency: Necrosis occurs due to the deficiency of Manganese Sulphate (Obaid et al., 2013)

Plant growth regulators: Plant growth regulators are essential for the production of high-quality produce. When plant growth regulators are applied to the foliage of the plants, the fruit set, yield of the plant, fruit retention increases. The physiology of the fruits is enhanced thus resulting in the decrease of physiological disorders of the fruit crop (Bons et al., 2020).

\section{Role of Micronutrients in fruit crops}

Papaya: During the $4^{\text {th }}, 8^{\text {th }}, 12^{\text {th }}$ month of planting followed by using zinc as a spray with $0.5 \%$ and boron $0.1 \%$ was essential for the increase in the yield of fruit and latex and its fruiting characteristics (Kavitha et al., 2000a).

Banana: In Karupalli banana leaves the micronutrients content increased on application of \% and ppm of Iron, Zinc and Boron (Jeyabaskaran and Pandey, 2008).

Guava: 50\% more flowers were obtained when both zinc and ferrous sulphate were applied at $0.3,0.4,0.5 \%$ concentration (Sarolia et al., 2007).

Grapes: acidity is reduced and TSS is increased on the application of $0.4 \%$ of Boron and Zinc (Singh et al., 2002).

Mango: fruit characteristics like fruit set and increased in value of fruits at harvest was attained on application of $10 \%$ Boric acid (Jarande et al., 2013). 
Strawberry: Petiole diameter, leaf characteristics and yield were improved on application of zinc sulphate $(0,100,200 \mathrm{mg})$ and boric acid $(0,150,300 \mathrm{mg})$ concentration (Abdollahi et al., 2010).

Aonla: Fruit drop, yield, volume and fruit size were increased on application of 2\%boron and $5 \%$ zinc sulfate (Verma et al., 2008).

Phalsa: High yields of variety Purple Round was achieved on application of Zinc sulfate (0.2,0.4,0.6\% concentration), urea $(1.0,1.5$, $2.0 \%)$, potassium sulphate $(1.0,1.5,2.0 \%)$ concentration (Wali et al., 2005).

Citrus: Sugars and ascorbic acid content in fruits were maximum on spray application of $0.5 \% \mathrm{ZnSO} 4$ in mandarin orange (Haque et al., 2000).

Litchi: TSS and sugar acid ratio decreased, pulp characteristics increased on application of $\mathrm{ZnSO}_{4} 1 \%$ and Borax $0.4 \%$ (Rani and Brahmachari, 2001).

\section{Problems of fertilizer application}

Liquid fertilizers have a disadvantage that they contain large quantities of diluents, especially water. Handling becomes difficult and as a result unnecessary packaging and shipping costs is incurred.

Precipitation occurs during storage of the produce when the solid or liquid fertilizer is mixed with the available water, dilution is not seen. The economic value of the fertilizer is lost. To prevent such problems drip tubes, fertilizer injectors and other equipment's are used (Daniels, 2005).

\section{Management of nutrient stress}

Nutrients are essential components given to the plant. When they are given in excessive amount, they cause stress to the plant which make them very susceptible to pest, diseases and cause abiotic stress. Soil analysis, Plant analysis, use of nutrient efficient crops, water use efficiency can be done. (Singh et al., 2002). Nutrient efficiency is related to two pathways such as physiological and biochemical pathways which cause nutrient stress. A pathway called nutrient signalling pathway increases the uptake and use efficiency of the nutrient. The Nutrient Use Efficiency in the fruit crops is done on the basis on soil, crop growth and yield. (Yan et al., 2006)

\section{References}

Abdollahi, M., Eshghi, S. and Tafazoli, E. (2010). Interaction of paclobutrazol, boron and zinc on vegetative growth, yield and fruit quality of strawberry (Fragaria $x$ Ananassa Duch. Cv. Selva). J. Biol. Environ. Sci., 4(11):67-75.

Anonymous. (2013). Indian Horticulture Database 2012-2013, National Horticulture Board, pp. 100-05.

Barker, A.V. and D.J. Pilbeam. (2007). Handbook of plant nutrition. CRC Press, Boca Raton, FL.

Bons, H.K., and Kaur, M. (2020). Role of plant growth regulators in improving fruit set, quality and yield of fruit crops: a review. The Journal of Horticultural Science and Biotechnology, 95(2), 137-146.

British Columbia Ministry of Agriculture. (2012). Berry production guideBeneficial management practices for berry growers in British Columbia. BC Ministry Agr., Victoria, BC, Canada.

Bryla, D.R. and R.M.A. Machado. (2011). Comparative effects of nitrogen fertigation and granular fertilizer application on growth and availability 
of soil nitrogen during establishment of highbush blueberry. Front. Plant Sci. 2:1-8.

Bulovac, M.J., and Wittwer, S.H., Plant Physiol., 32, 428-35(1957).

Daniels, R. S. (2005). U.S. Patent No. 6,858,058. Washington, DC: U.S. Patent and Trademark Office.

Dhok, R. (2020). Effect of various elements on growth of Plants. Plant Nutrients.223-227

Ding, P., and Sidhu, M. S. (2008). Postharvest quality of Carica papaya var. Eksotika after foliar feeding treatment. Pertanika J. Trop Agric. Sci, 31, 141-146.

Engel, R, L.J Bruebaker, and T.J. Ornberg.2001. A chloride deficient leaf spot of WB881 Durum. Soil Sci. Soc. AM.J. 65:1448-1454.

Eryani- Raqeeb, A.A., T.M. Mahmud, S.R. Syed Omar, A.R. Mohamed Zaki, and A.R. Al Eryani. 2009. Effects of calcium and chitosan treatments on controlling anthracnose and postharvest quality of papaya.(Carica papaya L.). Intl. J. Agr. Res. 4:53-68.

Fageria, N. K. 2005. Soil fertility and plant nutrition research under controlled conditions: Basic principles and methodology. Journal of Plant Nutrition 28: 1-25.

Fageria, N. K. 2007. Soil fertility and plant nutrition research under field conditions: Basic principles and methodology. Journal of Plant Nutrition 30: 203-223.

Fageria, N. K., and V. C. Baligar. 2005. Nutrient availability. In: Encyclopedia of Soils in the Environment, ed. D. Hillel, pp. 63-71. San Diego, CA: Elsevier.

Gajalakshimi, S. and Abbasi, S.A. (2004). Neem leaves as a source of fertilizer cum-pesticide vermicompost. Bioresource Technology, 92(3).21-
296.

Gupta R, Chakrabarthy SK. Gibberellic acid in plant: still a mystery unresolved. Plant Signal. and Beha. 2013;8(9):25504.

Gupta, U. C., Kening, W. U., and Liang, S. (2008). Micronutrients in soils, crops, and livestock. Earth Science Frontiers, 15(5), 110-125.

Hanson, E.J. 2006. Nitrogen fertilization of highbush blueberry. Acta Hort. 715:347-351

Haque, R., Roy, A. and Pramanick, M. (2000). Response of foliar application of $\mathrm{Mg}, \mathrm{Zn}, \mathrm{Cu}$ and $\mathrm{B}$ on improvement of growth, yield and quality of Mandarin orange in Darjeeling Hills of West Bengal. Hort.J.,13(2):15-20.

Hart, J., B. Strik, L. White, and W. Yang. 2006. Nutrient management for blueberries in Oregon. Ore. St. Univ. Ext. Serv. Publ. EM 8918. Ore. St. Univ., Corvallis, OR.

Havlin JL, Beaton JD, Tisdale SL, Nelson WL (2004) Soil fertility and fertilizers. An introduction to nutrient management, 7 th edn. Prentice Hall, New Delhi.

Jadhav, P.B., Padhiar, B.V., Ahlawat, T.R. and Chavan, S.M., 2015. Record of peacock: as a pest in Papaya (Carica papaya) in south Gujarat. Int. J. Curr. Res., 7(8):19258-19259.

Jarande, S. D., Patel, B. N., Patel, B. B,, Patel, N.R. and Dhuda, H.D. (2013). Effect of sucrose and nutrient elements on fruit set and fruit yield of mango cv. Kesar, Crop Res., 46(1,2\&3): 142145.

Jeyabaskaran, K.J. and Pandey. S. D.(2008). Effect of foliar spray of micronutrients in banana under high soil $\mathrm{pH}$ condition. Indian J. Hort., 65(1):102105.

Jiao Y, Hendershot WH, Whalen JK (2004) Agricultural practices influence 
dissolved nutrients leaching through intact soil cores. Soil Sci Soc Am J 68:2058-2068

Kavitha M, Kumar N, Jeyakumar P (2000). Effect of zinc and boron on biochemical and quality characters of papaya cv.Co.5. South Indian Hortic.

Lester, G.E., Jifon, J.L. and Stewart, W.M. (2007). Foliar potassium improves cantaloupe marketable and nutritional quality. Better Crops, 91(1), 24-25.

McCauley, A., Jones, C., and Jacobsen, J. (2009). Plant nutrient functions and deficiency and toxicity symptoms. Nutrient management module, 9, 1-16.

Migliaccio KW, Schaffer B, Crane JH, Davies FS (2010) Plant response to evapotranspiration and soil water sensor irrigation scheduling methods for papaya production in south Florida. Agric Water Manag, 97: 1452-1460.

Obaid, E. A., and Al-Hadethi, M. E. A. (2013). Effect of foliar application with manganese and zinc on pomegranate growth, yield and fruit quality. J. Hort. Sci. and Ornamental Plants, 5(1), 41-45.

Prasad, A., Chattopadhyay, A., Yadav, A., and Kumari, R. (2008). Variation in the chemical composition and yield of essential oil of rose-scented geranium (Pelargonium sp.) by the foliar application of metallic salts. Flavour and fragrance journal,23(2), 133136.

Raja, E. M., 2009, Importance of micronutrients in the changing horticultural scenario. J. Hort. Sci., 4(1):1-27.

Rani, R. and Brahmachari, V.S. (2001). Effect of foliar application of calcium, zinc and boron on cracking and Physicchemical composition of litchi. Orissa J. Hort., 29(1): 50-57.
Riedell, W. E., and Schumacher, T. E. (2009). Transport of water and nutrients in plants. Agric Sci, 1, 372.

Sarolia, D.K., Rathore, N.S. and Rathore, R.S. (2007). Response of Zinc Sulphate and iron sulphate sprays on growth and productivity of guava cv. Sardar. Curr.Agric., 31(1-2):73-77.

Saure, M.C. 2005. Calcium translocation to fleshy fruit: Its mechanism and endogenous control. Sci. Hort. 105:65-89.

Silva VPR, Campos JHBC, Azevedo PV (2009) Water-use efficiency and evapotranspiration of mango orchard grown in northeastern region of Brazil. Sci Hortic 120:467-472.

Singh, C., Sharma, V.P., Usha, K. and Sagar, V.R. (2002). Effect of macro and micronutrients on Physico-chemical characters of grape cv. Perlette. Indian. J. Hort., 59(3): 258-260.

Singh, A. L. (2002). Macronutrient stresses and interaction of nutrients in plants. Physiology Of Abiotic Stresses In Plants (Eds RS Dwivedi and $P$. Dwivedi), pp Oxford IBH Publishers, New Delhi, India.

Singh, A.K., Prasad, V.M., Singh, D., Bahadur, V., Thomas, T., \&Kumar,A. (2018). Effect of Different Combinations of PGR'S and Micronutrients on Quality in Papaya (Carica papaya L.) cv. Pusa Nanha. Int. J. Curr. Microbiol. App. Sci, 7(9), 2813-2820.

Suryawanshi, M.D. (2020). Plant Nutrients TYBSC.

Vargas, O. L., and Bryla, D. R. (2015). Growth and fruit production of highbush blueberry fertilized with ammonium sulfate and urea applied by fertigation or as granular fertilizer. HortScience, 50(3), $\quad$ 479485.

Verma, R.S,; Singh P.C. and Chaturvedi, O.P. 
(2008). Effect of foliar sprays of zinc and boron on the physical parameters of aonla (Emblica officinalis Gaertn.) fruits cv. Banarasi. Asian Journal of Horti. 3(20): 344-345.

Wali, V.K., Kaul, R. and Khler.(2005). Effect of foliar sprays of nitrogen, potassium and Zinc on yield and Physicochemical composition of phalsa (Grewia subinaequalis DL) cv. Purple Round. Haryana J. of Horti. Sci.
34(1/2): 56-57.

White, P.J. 2001. The pathways of calcium movement to the xylem. J. Expt. Bot. 50: 891-899.

White, P.J. and M.R. Broadley.2003. Calcium in plants. Ann. Bot. (Lond.) 92:487511.

Yan, Xiaolong, Wu Ping, Ling Hongqing, Xu Guohna, Xu Fangsen and Zhang Qifa, Ann. Bot. 98: 473- 82 (2006).

\section{How to cite this article:}

Victoria Joan Johnson and Anis Mirza. 2020. Role of Macro and Micronutrients in the Growth and Development of Plants. Int.J.Curr.Microbiol.App.Sci. 9(11): 576-587.

doi: https://doi.org/10.20546/ijcmas.2020.911.071 